\title{
Optimization Method for Simultaneous Extraction and Detection of Imazapic and Imazapyr Herbicides in Soil and Water Using HPLC-UV with Verification of LC-MS (Kaedah Pengoptimuman bagi Mengekstrak dan Mengesan Herbisid Imazapic dan Imazapyr secara Serentak dalam Tanah dan Air Menggunakan HPLC-UV dengan Ujian Pengesahan LC-MS)
}

\author{
BAJRAI, F.S.M.,* ISMAIL, B.S.\& MARDIANA-JANSAR, K.
}

\begin{abstract}
The residual activity of herbicides in soil and water may be detrimental to the environment. This issue has caught the attention of environmentalists and among the herbicides concerned are a mixture of Imazapic and Imazapyr, also known as OnDuty®, which is currently being used in the Clearfield@ Production System. These herbicides are widely used to control weedy rice in rice fields. In order to determine their residues in both soil and water, an accurate and simple method of extraction has to be developed. In the present study, extraction processes followed by HPLC-UV Separation was developed and validated for simultaneous determination of imazapic and imazapyr in two matrices, namely soil and water. Verification of chemical compounds was then determined by using LC-MS (ToF). Recovery values of imazapic and imazapyr using $10 \mu \mathrm{M}$ ammonium acetate extraction from blank samples spiked at levels between $1 \mathrm{mg} \mathrm{L}^{-1}$ and $10 \mathrm{mg} \mathrm{L}^{-1}$ in soil and water were $83 \%$ to $106 \%$ (with $R S D \leq 9 \%$ ). The limit of detection (LOD) ranged from 0.25 to $0.46 \mathrm{mg} \mathrm{L}^{-1} \mathrm{while}$ the limit of quantification (LOQ) was from 0.74 to $1.37 \mathrm{mg} \mathrm{L}^{-1}$. LC-MS (ToF) mass spectrum analyses of imazapyr and imazapic were obtained at $\mathrm{m} / \mathrm{z}, 262.12$ with the retention time of 2.39 min and $\mathrm{m} / \mathrm{z} 276.13$ with the retention time of 3.06 min, respectively. This method would be helpful in determining the level of pesticides in soil and water in a shorter time $(<6 \mathrm{~min})$
\end{abstract}

Keywords: Herbicides; HPLC-UV; LC-MS (ToF); imazapyr; imazapic

\section{ABSTRAK}

Aktiviti sisa herbisid di dalam tanah dan air boleh memudaratkan alam sekitar. Isu ini telah mendapat perhatian daripada pencinta alam sekitar dan antara herbisid berkenaan adalah campuran Imazapic dan Imazapyr, juga dikenali sebagai OnDuty $\AA^{\circledR}$ yang kini digunakan dalam Sistem Pengeluaran Clearfield®. Herbisid ini digunakan secara meluas untuk mengawal rumpai padi di sawah padi. Dalam usaha untuk menentukan sisa racun tersebut dalam kedua-dua tanah dan air, maka satu kaedah yang tepat dan mudah untuk pengekstrakan perlu dibangunkan. Dalam kajian ini, satu kaedah pengekstrakan menggunakan 10 \% M ammonium asetat diikuti oleh pemisahan HPLC-UV telah dibangunkan dan disahkan untuk penentuan serentak terhadap imazapic dan imazapyr dalam dua matrik, iaitu tanah dan air. Selanjutnya, ujian pengesahan sebatian kimia dilakukan dengan menggunakan LC-MS (ToF). Nilai pemulihan imazapic dan imazapyr dicapai dalam sampel kosong yang disuntik pada kepekatan antara 1 dan $10 \mathrm{mg} \mathrm{L}^{-1}$ di dalam tanah dan air adalah $83 \%$ hingga $106 \%$ (dengan RSD $\leq 9 \%$ ) dengan had pengesanan (LOD) antara 0.25 hingga $0.46 \mathrm{mg} \mathrm{L}^{-1}$ manakala had kuantifikasi (LOQ) adalah daripada 0.74 kepada $1.37 \mathrm{mg} \mathrm{L}^{-1}$. Analisis LC-MS (ToF) bagi mengenal pasti berat spektrum imazapyr dan imazapic masing- masing dapat dicapai pada m/z 262.12 dengan masa penahanan 2.39 min dan m/z.276.13 dengan masa penahanan 3.06 min. Kaedah ini akan dapat membantu dalam menentukan tahap herbisid dalam tanah dan air dalam masa yang singkat ( $<6 \mathrm{~min})$.

Kata kunci: Herbisid; HPLC-UV; LC-MS (ToF); imazapic; imazapyr

\section{INTRODUCTION}

Herbicides are being used in the agricultural sector to control weeds in plantations as well as in rice fields (Rekha et al. 2006), in order to enhance food production, reduce labour cost and control weeds more effectively. Since weeds can be controlled at the initial stages of their growth, ploughing activities would be reduced and thus moisture and nutrient content in the soil maintained. In rice fields, weeds are among the main problems besides pests and diseases. Since 1990, weedy rice has been a serious problem in paddy growing areas (Karim et al. 2004). The imidazolinone group of herbicides along with new varieties of paddy namely MR 220 CL1 and MR220 CL2 were introduced to farmers in order to control weedy rice (Azmi et al. 2012).

Application of the imidazolinone herbicides is currently becoming more popular in paddy planting areas of Malaysia. Imazapic and imazapyr (slightly different in structure as portrayed in Figure 1) belong to the imidazolinone group and are used in combination 
with imidazolinone-tolerant rice varieties for controlling weedy rice (but not the paddy plants) (Terano et al. 2016). They were first introduced into Malaysia in the year 2010 (Azmi et al. 2012; Bajrai et al. 2015). Imazapic and imazapyr (categorized in the imidazolinone group) control several types of grasses and broadleaf weeds, as well as woody plants (Ulbrich et al. 2005). They have the ability to control a broad spectrum of weeds at extremely low dosages. However, they might have high persistency in the soil (Senseman et al. 2007). Both compounds share the same mode of action, whereby they act as inhibitors to amino acid synthesis and thus prevent the synthesis of the amino acids required for the production of proteins (Tu et al. 2001).

Compound

FIGURE 1. Chemical structure, molar mass and $\mathrm{pKa}$ values of imazapic and imazapyr

Adverse environmental consequences associated with pesticide use have created public awareness and concern over their potential long-term health risks. Consumers are becoming more aware regarding the safety of food produced and thus the concerns on the effects of pesticides with regard to human health and the environment are no longer taken for granted (Wee 2005; Xavier et al. 2004). Therefore, several studies have been conducted to determine herbicide residues in the urine of dairy cows (Krüger et al. 2014), soil and water (Assalin et al. 2014; Süzer \& Büyük 2010), sediment (Devault et al. 2007) as well as in vegetables (Lee et al. 2015; SaitoShida et al. 2016) with the use of High Performance
Liquid Chromatography (HPLC) and Gas Chromatography (GC).

To date, studies on the detection of imazapic and imazapyr in soil had been conducted separately with good recovery (de Oliveira Arias et al. 2014; Ramezani et al. 2009) and simultaneously with poor recovery rates (D’Ascenzo et al. 1998). Separate studies on the detection of imazapic and imazapyr in water samples with good recovery rates were also reported by Börjesson et al. (2004) and Martini et al. (2013). These developments encouraged the creation of new methodology and the improvement of existing methods used for the determination of pesticide residues in food and environmental matrices. The analysis and extraction of both imazapic and imazapyr from environmental samples has yet to be determined by one single analytical procedure which would definitely save time of analysis and be more cost effective. The present study was conducted to investigate the optimization method for both the compounds in environmental samples, namely water and soil using one single analytical procedure.

\section{MATERIALS AND METHODS}

\section{MATERIALS AND REAGENTS}

All reagents used were of analytical grade unless specified otherwise. The HPLC grade solvents including methanol $(\mathrm{MeOH})$ and acetonitrile $(\mathrm{ACN})$ were purchased from MERCK (Damstadt, Germany). Formic acid and acetic acid (Glacial) were also purchased from the same supplier. The mobile phase solutions were prepared with ultra-pure water from Mili-Q (Milipore Corp., USA). Analytical grade imazapic, of purity $98.5 \%$ and imazapyr, of purity $99.5 \%$ were obtained from Dr Ehrenstorfer (Germany). The physico-chemical properties of imazapic and imazapyr are shown in Table 1. Extraction processes were conducted using 0.5 M sodium hydroxide (Ramezani et al. 2009), $10 \mu \mathrm{M}$ ammonium acetate (Moser 2010) and 0.1 M potassium chloride (Gianelli et al. 2014), that were prepared with ultra-pure water.

\section{PREPARATION OF STANDARD STOCK SOLUTION}

The standard stock solution of imazapic and imazapyr (100 $\mathrm{mg} \mathrm{mL}^{-1}$ ) in methanol was prepared and kept at $4^{\circ} \mathrm{C}$ prior to analysis. The working standard solutions of $1,2,3$, 4,5 , and $10 \mathrm{mgL}^{-1}$ were prepared from the stock solution.

TABLE 1. Physical and chemical properties of Imazapic and Imazapyr

\begin{tabular}{lcc}
\hline \multirow{2}{*}{ Properties } & \multicolumn{2}{c}{ Technical Herbicide } \\
\cline { 2 - 3 } & Imazapyr & Imazapic \\
\hline Empirical formula & $\mathrm{C}_{13} \mathrm{H}_{15} \mathrm{~N}_{3} \mathrm{O}_{3}$ & $\mathrm{C}_{14} \mathrm{H}_{17} \mathrm{~N}_{3} \mathrm{O}_{3}$ \\
Molecular Weight & 261 & 275 \\
Physical state & White-to-tan powder & Off-white-to-tan powder \\
Melting Point & $269-273^{\circ} \mathrm{C}$ & $204-206^{\circ} \mathrm{C}$ \\
Vapour pressure & $<1 \times 10^{-} 7 \mathrm{mmHg}$ at $60^{\circ} \mathrm{C}$ & $<1 \times 10^{-} 7 \mathrm{mmHg}$ at $60^{\circ} \mathrm{C}$ \\
\hline
\end{tabular}




\section{RECOVERY TEST}

For the recovery test, three different concentrations of imazapic and imazapyr, ie; 1, 5 and $10 \mathrm{mg} \mathrm{L}^{-1}$ were prepared. Each soil and water sample was treated with the combination of both imazapyr and imazapic. The pesticides were then extracted from the soil and water by using several extraction methods for determination of the residue of imazapic and imazapyr. According to Ramezani et al. (2009), extraction by using 0.5 M sodium hydroxide $(\mathrm{NaOH})$ solution gave a good recovery for imidazolinone herbicides in the soil. $10 \mathrm{~g}$ of soil and wáter samples were weighed and treated with the combination of both imazapyr and imazapic standard solution. They were left for $1 \mathrm{~h}$ before the extraction solution was added. Then, $40 \mathrm{~mL}$ of $\mathrm{NaOH}$ was added to the samples, shaken for $1 \mathrm{~h}$ on an orbital shaker and finally centrifuged for $10 \mathrm{~min}$ at a speed of 4000 $\mathrm{rpm}$. The supernatant was passed through over stacking $\mathrm{C}_{18}$ and SCX SPE cartridges. $2.5 \mathrm{~mL}$ of the supernatant was then filtered using polyamide nylon $(0.20 \mathrm{~m})$ and finally were analysed by using a HPLC (Agilent Technology Model 1220 LC equipped with an UV detector).

Analyses of the samples of water and soil were also carried out using the method proposed by Moser (2010), with slight modifications. The soil and water samples $(5 \mathrm{~g}$ each) were placed separately in $50 \mathrm{~mL}$ centrifuge tubes. The extraction was carried out by initially adding $10 \mathrm{~mL}$ of $10 \mu \mathrm{M}$ ammonium acetate, $0.5 \mathrm{M}$ sodium hydroxide and $0.1 \mathrm{M}$ potassium chloride to the samples. The mixture was then shaken in a vortex mixer for $30 \mathrm{~s}$ and centrifuged for $5 \mathrm{~min}$ at the speed of $4000 \mathrm{rpm}$. Then $1.0 \mathrm{~mL}$ of the supernatant from each extraction was directly injected into $2 \mathrm{~mL}$ vials via a $0.2 \mathrm{~m}$ nylon filter. Analyses were carried out using a HPLC (Agilent Technology Model 1220 LC equipped with an UV detector).

The method proposed by Gianelli et al. (2014) for extraction of imidazolinone herbicides was conducted using $0.1 \mathrm{M}$ potassium chloride. $5 \mathrm{~g}$ soil and water samples were placed in $50 \mathrm{~mL}$ centrifuged tube and added with $1 \mathrm{~mL}$ of imazapic and imazapyr standard solution. They were left for $1 \mathrm{~h}$ prior to extraction process. $20 \mathrm{~mL}$ of solvent extraction (potassium chloride) was added to the sample. The mixture was then shaken for $20 \mathrm{~min}$ on a vortex, put in an ultrasonic for $15 \mathrm{~min}$ and then centrifuged for $15 \mathrm{~min}$ at a speed of $2500 \mathrm{rpm} .1 .0 \mathrm{~mL}$ of the supernatant from each extraction was directly injected into $2 \mathrm{~mL}$ vials via a $0.2 \mathrm{~m}$ nylon filter. Analyses were carried out using a HPLC (Agilent Technology Model 1220 LC equipped with an UV detector).

\section{HIGH PERFORMANCE LIQUID} CHROMATOGRAPHIC ANALYSIS

Analyses were carried out using a HPLC (Agilent Technology Model 1220 LC) equipped with an UV detector, quaternary pump, thermostatic column compartment, vacuum degasser, auto-sampler and a variable wavelength detector. The collected data was processed using a LC workstation with Chemstation software. The mobile phase that consisted of solvents and solutions was initially filtered and degassed by ultrasound. The chromatographic separation was done using the Agilent column ZORBAX Eclipse Plus $\mathrm{C}_{8}(2.1 \times 150 \mathrm{~mm}$ id, $5 \mu \mathrm{m}$ particle size $)$ (Krynitsky et al. 1999). Factors such as variation in the wavelength, mobile phase ratio, acid composition of the mobile phase and flow rate were studied. In the meantime, the temperature of the column was kept constant at $25 \pm 3^{\circ} \mathrm{C}$ for optimization of the separation method of the analytes. The method was validated using the following criteria: calibration, limit of detection (LOD), limit of quantification (LOQ), linearity, repeatability and recovery percentage. For validation of the method, samples were analysed using optimal conditions of the HPLC column.

\section{LIQUID CHROMATOGRAPHY WITH MASS SPECTROMETRY (LC-MS) ANALYSIS}

Verification of chemical compounds can be determined using LC-MS by identifying the mass spectrum of the compound in the standard solution. Various studies had been conducted in identifying imazapic and imazapyr using LC-MS or LC-MS/MS (D'Ascenzo et al. 1998; de Oliveira Arias et al. 2014; Lin et al. 2007; Ramezani et al. 2009). Therefore, the present study in determining the mass spectrometry of both compounds opted for the HPLC (Dionex Ultimate 3000 DAD) analysis connected to the LC-MS (ToF) of Brunker (MicrOTOF-Q) with detector Electron Spray Ionization (ESI) in a positive mode. The capillary column and the mobile phase used were similar to that in the HPLC-UV analysis, running at a flow rate of $0.03 \mathrm{~mL} / \mathrm{min}$. Table 3 shows the mass spectroscopy parameters used in the analysis of imazapic and imazapyr. The above analysis was carried out in ToF Analysis Laboratory at the Centre for Research and Instrumentation (CRIM), Universiti Kebangsaan Malaysia.

\section{RESULTS AND DISCUSSION}

\section{THE HPLC-UV CONDITIONS: DETERMINATION OF THE OPTIMUM WAVELENGTH}

The different wavelengths of the HPLC-UV set as the detector wavelength were as follows: 230, 240, 255, 270 and $285 \mathrm{~nm}$. The wavelength, $255 \mathrm{~nm}$ (1max) showed maximum absorbance of the analytes for both imazapic and imazapyr (Figure 2). Therefore, this wavelength (1max) of $255 \mathrm{~nm}$ was selected as the maximum wavelength for simultaneous determination.

\section{SELECTIVITY OF THE MOBILE PHASE}

The selection of a suitable organic solvent, involved making modifications to get the right combination of solvents in the mobile phase of the HPLC-UV analysis. The mobile phase solvents that are often used in the analysis of imidazolinone compounds are acetonitrile, methanol $(\mathrm{MeOH})$, formic acid and acetic acid (Assalin et al. 2014; Lao \& Gan 2006; Martins et al. 2014; Ramezani et al. 


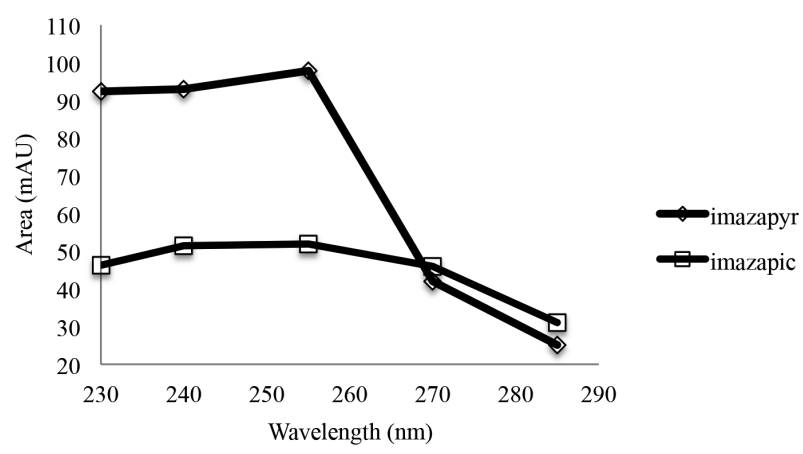

FIGURE 2. Maximum absoprtion area (mAU) at the wavelengths of 230 to $285 \mathrm{~nm}$

2009). Four mixtures of solvents were tested: mobile phase A (acetonitrile) and mobile phase B (0.1\% formic acid); mobile phase A (methanol) and mobile phase B ( $0.1 \%$ formic acid); mobile phase A (acetonitrile) and mobile phase B $(0.1 \%$ acetic acid $)$; and mobile phase A (methanol) and mobile phase B $(0.1 \%$ acetic acid). The results showed that the peak responses showed almost no major differences for all combinations of the mobile phase. A better separation and resolution (highest mAU) for both compounds was obtained when a combination of acetonitrile and $0.1 \%$ formic acid was used: with this mixture of solvents it took less than 6 min for both compounds to be separated (Figure 3).

\section{EFFECT OF THE MOBILE PHASE COMPOSITION}

In the HPLC-UV analysis, the mobile phase composition plays an important part in the separation of compounds. Acetonitrile and formic acid were selected for the mobile phase in the analysis based on the initial results obtained in the above experiments. The combination of mobile phase A (acetonitrile) and $\mathrm{B}(0.1 \%$ formic acid) in the ratio of 20A:80B; (v/v), 30A:70B; (v/v) and 45A:55B; $(\mathrm{v} / \mathrm{v})$ were tested in the experiments. The ratio of 20A:80B; (v/v) was found to be optimal for sharp peaking of the compound with more stable baseline (Figure 4) and therefore, it was finally selected. As for the mixture of $45 \mathrm{~A}: 55 \mathrm{~B} ;(\mathrm{v} / \mathrm{v})$, shorter retention time was taken in the separation process but less peak area was obtained for both compounds.

\section{EFFECT OF THE FLOW RATE}

According to Akkbik et al. (2011), the flow rate has an important role in influencing the retention time and peak area, but has little effect on the separation. A flow rate of $0.3 \mathrm{~mL} \mathrm{~min}{ }^{-1}$ was selected as the optimum setting for the HPLC analysis due to its satisfactory area size and retention time which fell between at 2.99 and $4.55 \mathrm{~min}$ for complete elution of the compound from the column, especially when the setting was used to run the samples (Table 2).

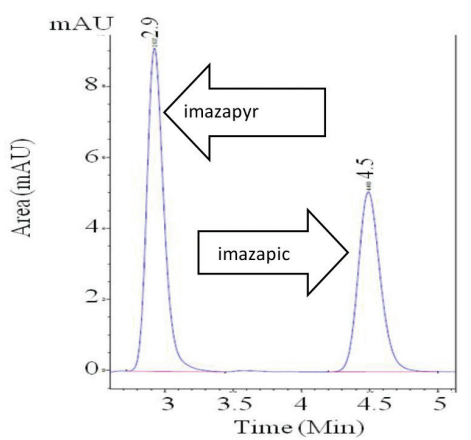

(a)

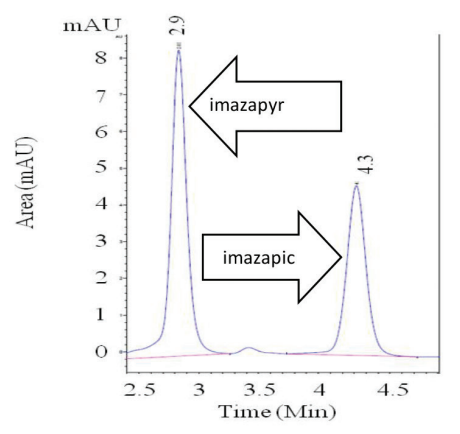

(c)

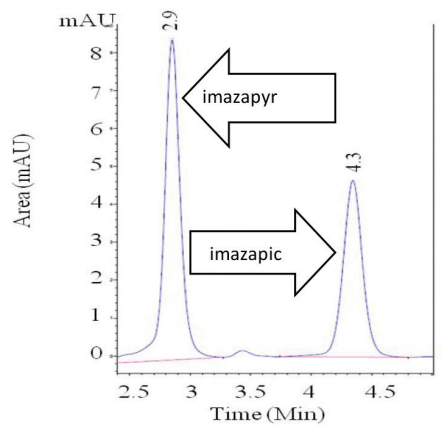

(b)

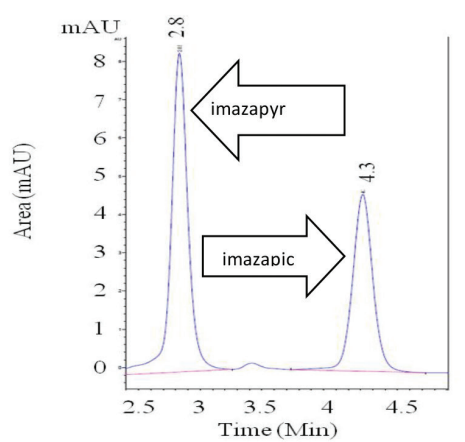

(d)

FIGURE 3. Maximum absoprtion of imazapic and imazapyr at a) A (acetonitrile): B ( $0.1 \%$ formic acid); b) A $(\mathrm{MeOH}): \mathrm{B}(0.1 \%$ formic acid); c) A (acetonitrile): B (0.1\% acetic acid); d) A (MeOH): B $(0.1 \%$ acetic acid $)$ 


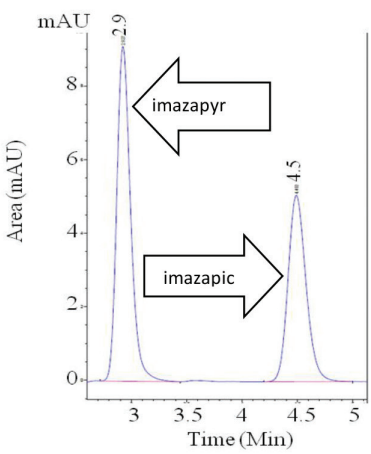

(a)

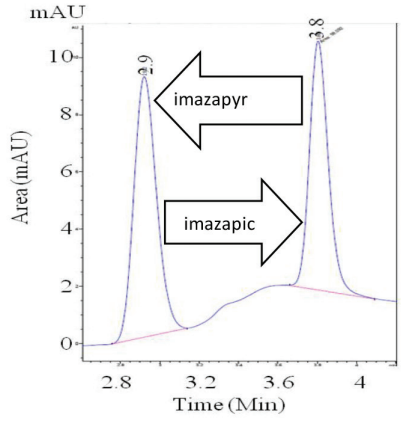

(b)

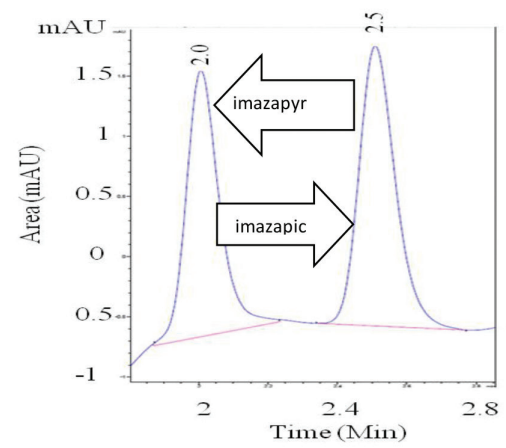

(c)

FIGURE 4. Maximum absoprtion of imazapic and imazapyr at a) 20\% A (acetonitrile): $80 \%$ B ( $0.1 \%$ formic acid); b) $30 \% \mathrm{~A}$ (acetonitrile): $70 \% \mathrm{~B}$ ( $0.1 \%$ formic acid) and c) $45 \% \mathrm{~A}$ (acetonitrile): $55 \% \mathrm{~B}(0.1 \%$ formic acid)

TABLE 2. Effect of flow rate on absorption area (mAU) and retention time

\begin{tabular}{lcccccc}
\hline & \multicolumn{3}{c}{ Imazapyr } & \multicolumn{3}{c}{ Imazapic } \\
\cline { 2 - 7 } Compounds & \multicolumn{3}{c}{ Flow rate of the mobile phase $\left(\mathrm{mL} \mathrm{min}^{-1}\right)$} \\
\cline { 2 - 7 } & 0.2 & 0.3 & 0.5 & 0.2 & 0.3 & 0.5 \\
\hline Maximum absorption area (mAU) & 97.8 & 118.4 & 33.8 & 51.9 & 86.4 & 29.5 \\
Retention time, RT (min) & 4.3 & 2.9 & 2.6 & 6.6 & 4.5 & 4.2 \\
\hline
\end{tabular}

\section{VALIDATION METHOD}

The validation steps for imazapic using the HPLC-UV was done under the optimized conditions of $255 \mathrm{~nm}$ as maximum wavelength, $0.3 \mathrm{~mL} \mathrm{~min}^{-1}$ as flow rate, with the mobile phase combination of $\mathrm{A}$ (acetonitrile) and $\mathrm{B}$ (formic acid $0.1 \%)$ at the ratio of $20 \mathrm{~A}: 80 \mathrm{~B} ;(\mathrm{v} / \mathrm{v})$ for elution and with the duration of analysis of $6 \mathrm{~min}$ for both compounds.

\section{LINEARITY, LIMIT OF DETECTION (LOD), LIMIT OF QUANTIFICATION (LOQ) AND RECOVERY}

Blank samples of water and soil were spiked at 1,5 and $10 \mathrm{mg} \mathrm{L}^{-1}$ with six replications for each spiked level, to determine the precision of the method. Relative standard deviation (RSD) of the six replicates was calculated to evaluate the precision of the method. According to Assalin et al. (2014) the LOQ parameter was determined as the lowest injected pesticide concentration resulting in RSD $\leq 20 \%$ for the 6 replicates. In the present study, the limit of detection (LOD) and limit of quantification (LOQ) were estimated at a signal to the noise ratio of $3: 1$ and 10:1, respectively. Studies done by Saadati et al. (2013); Singh (2013) and Tian et al. (2014) suggested that LOD and LOQ were determined based on the response and slope of a specific calibration curve obtained. Based on the standard calibration curve in Figure 7, the standard calibration curves of imazapic and imazapyr were linear for 1 to $5 \mathrm{mg}$ $\mathrm{L}^{-1}$ concentration, with the coefficient of determination $\left(\mathrm{R}^{2}\right)$ above 0.99 . The equation of the calibration curve is shown in Figure 7. The results obtained as shown in Table 5 shows an acceptable relative standard deviation percentage (RSD $\%$ ) ranging from $1 \%$ to $9 \%$ at the retention time of 2.9 and 4.5 min, which did not exceed $20 \%$. 
TABLE 3. LC-MS (ToF) parameter

\begin{tabular}{lc}
\hline Parameter & Value \\
\hline Capillary volt & $4000 \mathrm{~V}$ \\
Nebulizer pressure & $4 \mathrm{bar}$ \\
Dry gas & $8.0 \mathrm{~L} / \mathrm{min}$ \\
Dry heater & $190^{\circ} \mathrm{C}$ \\
The mass spectrum range & $50-600 \mathrm{~m} / \mathrm{z}$ \\
\hline
\end{tabular}

Table 4 summarizes the recovery percentage for imazapyr and imazapic using several extraction procedures at $1 \mathrm{mg} \mathrm{L}^{-1}$. The recovery percentage for imazapyr using $0.5 \mathrm{M}$ sodium hydroxide and $0.1 \mathrm{M}$ potassium chloride for solvent extractions from water at a concentration of $1 \mathrm{mg} \mathrm{L}^{-1}$ was $71.93 \%$ and $82.14 \%$, respectively. However, for imazapic, the recovery percentage from water by using similar extraction solutions; at a concentration of $1 \mathrm{mg} \mathrm{L}^{-1}$ was only $43.59 \%$ and $54.43 \%$, respectively. As for the recovery from soil at $1 \mathrm{mg} \mathrm{L}^{-1}$, the extraction using $0.5 \mathrm{M}$ sodium hydroxide and $0.1 \mathrm{M}$ potassium chloride as solvent, gave a recovery percentage for imazapyr at $76.87 \%$ and $69.37 \%$, respectively. For imazapic on the other hand, the recovery percentage from soil for solvent concentration of $1 \mathrm{mg} \mathrm{L}^{-1}$ was obtained at $51.69 \%$ and $49.10 \%$, respectively. The recovery findings by using different extractions indicated that they differ statistically at the concentrations of $1 \mathrm{mg} \mathrm{L}^{-1}$. These findings indicated that the solvent concentrations used were effective in extracting the imazapyr compound as reported by Ramezani et al. (2009) and Gianelli et al. (2014) but not as effective to detect the imazapic compound from both the water and soil matrix.

The recovery percentage (Table 5 and Figure 5) for imazapyr using $10 \mu \mathrm{M}$ ammonium acetate for solvent extraction from water at concentrations of 1,5 and $10 \mathrm{mg} \mathrm{L}^{-1}$ ranged from $88 \%$ to $106 \%$. Furthermore, for imazapic, the recovery percentage (Table 5 and Figure 5) from water at concentrations of 1,5 and $10 \mathrm{mg} \mathrm{L}^{-1}$ ranged from $100 \%$ to $101 \%$. With regard to recovery from soil (Table 5 and Figure 6), for the extraction using $10 \mu \mathrm{M}$ ammonium acetate as solvent, the recovery percentage for imazapyr at solvent concentrations of 1,5 and $10 \mathrm{mg} \mathrm{L}^{-1}$ ranged from $83 \%$ to $97 \%$. For imazapic on the other hand, the recovery percentage (Table 5 and Figure 6) from soil for the solvent concentrations of 1,5 and $10 \mathrm{mg} \mathrm{L}^{-1}$ ranged from $91 \%$ to 97\%. A study done by Kemmerich et al. (2015) showed that ammonium acetate had high potential to be used in the extraction of imidazolinone compounds in the soil.

\section{MASS SPECTROMETRY ANALYSIS}

Figure 8 shows the mass spectrum of the compounds obtained from LC-MS analysis. The ion peak of imazapyr was obtained at $\mathrm{m} / \mathrm{z} 262.12$ with the retention time of $2.39 \mathrm{~min}$; and imazapic at $\mathrm{m} / \mathrm{z} 276.13$ with the retention time of $3.06 \mathrm{~min}$. These peaks correspond to the molecular mass of imazapyr and imazapic as portrayed in Figure 1 as well as Table 1. Furlong et al. (2000), Laganà et al. (1998) and Rodriguez and Orescan (1998) reported similar results of $\mathrm{m} / \mathrm{z} 262$ for the imazapyr compound using LC-MS. Previous studies carried out using LC-MS also supported the

TABLE 4. Results of recovery for Imazapic and Imazapyr in soil and water at $1 \mathrm{mg} \mathrm{L}^{-1}$ using several extractions method

\begin{tabular}{|c|c|c|c|c|}
\hline \multirow{2}{*}{ Extraction solutions } & \multicolumn{2}{|c|}{ Mean recovery in water $(\%) \pm \mathrm{SD}^{\#}$} & \multicolumn{2}{|c|}{ Mean recovery in soil $(\%) \pm \mathrm{SD}^{\#}$} \\
\hline & Imazapyr & Imazapic & Imazapyr & Imazapic \\
\hline $0.5 \mathrm{M} \mathrm{NaOH}+$ SPE Cartridges $\left(\mathrm{C}_{18} \& \mathrm{SCX}\right)$ & $71.93 \pm 2.67$ ab & $43.59 \pm 2.06^{\mathrm{b}}$ & $76.87 \pm 1.66^{\mathrm{b}}$ & $51.69 \pm 2.07^{b}$ \\
\hline $10 \mu \mathrm{M}$ ammonium acetate & $88.24 \pm 7.64^{\mathrm{a}}$ & $100 \pm 6.61^{\mathrm{a}}$ & $97.06 \pm 2.94^{\mathrm{a}}$ & $97.44 \pm 4.44^{\mathrm{a}}$ \\
\hline $0.1 \mathrm{M} \mathrm{KCl}$ & $82.14 \pm 2.57^{b}$ & $54.43 \pm 3.44^{\mathrm{b}}$ & $69.37 \pm 3.44^{\mathrm{c}}$ & $49.10 \pm 1.96^{b}$ \\
\hline
\end{tabular}

"Means followed by a similar letter within a column for a particular extraction are not significantly different at $p<0.05$ level of significant based on Tukey's HSD mean separation test

TABLE 5. Results of recovery, linearity, LOD and LOQ of the validation method

\begin{tabular}{|c|c|c|c|c|c|c|c|c|c|c|}
\hline \multirow{2}{*}{ Compounds } & \multirow{2}{*}{$\begin{array}{c}\text { Retention } \\
\text { time, RT } \\
\text { (minutes) }\end{array}$} & \multicolumn{3}{|c|}{$\begin{array}{l}\text { Repeatability recovery of water } \\
\qquad(\mathrm{RSD} \%)^{\#}\end{array}$} & \multicolumn{3}{|c|}{$\begin{array}{l}\text { Repeatability recovery of soil } \\
\qquad(\mathrm{RSD} \%)^{*}\end{array}$} & \multirow{2}{*}{$\begin{array}{l}\text { Linearity } \\
\qquad\left(\mathrm{R}^{2}\right)\end{array}$} & \multirow{2}{*}{$\begin{array}{c}\text { LOD } \\
\left(\mathrm{mg} \mathrm{L}^{-1}\right)\end{array}$} & \multirow{2}{*}{$\begin{array}{c}\mathrm{LOQ} \\
\left(\mathrm{mg} \mathrm{L}^{-1}\right)\end{array}$} \\
\hline & & $\begin{array}{c}1 \\
\left(\mathrm{mg} \mathrm{L}^{-1}\right)\end{array}$ & $\begin{array}{c}5 \\
\left(\mathrm{mg} \mathrm{L}^{-1}\right)\end{array}$ & $\begin{array}{c}10 \\
\left(\mathrm{mg} \mathrm{L}^{-1}\right)\end{array}$ & $\begin{array}{c}1 \\
\left(\mathrm{mg} \mathrm{L}^{-1}\right)\end{array}$ & $\begin{array}{c}5 \\
\left(\mathrm{mg} \mathrm{L}^{-1}\right)\end{array}$ & $\begin{array}{c}10 \\
\left(\mathrm{mg} \mathrm{L}^{-1}\right)\end{array}$ & & & \\
\hline Imazapyr & 2.93 & $88(9)^{\mathrm{a}}$ & $88(9)^{a}$ & $106(3)^{\mathrm{a}}$ & $97(3)^{\mathrm{a}}$ & $83(1)^{a}$ & $95(3)^{\mathrm{a}}$ & 0.99 & 0.25 & 0.74 \\
\hline Imazapic & 4.50 & $100(7)^{\mathrm{a}}$ & $100(7)^{\mathrm{a}}$ & $101(2)^{\mathrm{a}}$ & $97(5)^{\mathrm{a}}$ & $91(3)^{\mathrm{a}}$ & $96(3)^{\mathrm{a}}$ & 0.99 & 0.45 & 1.37 \\
\hline
\end{tabular}

$* n=6$

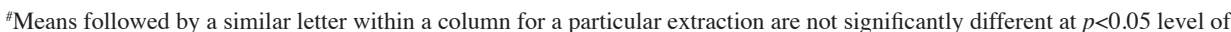
significant based on Tukey's HSD mean separation test 

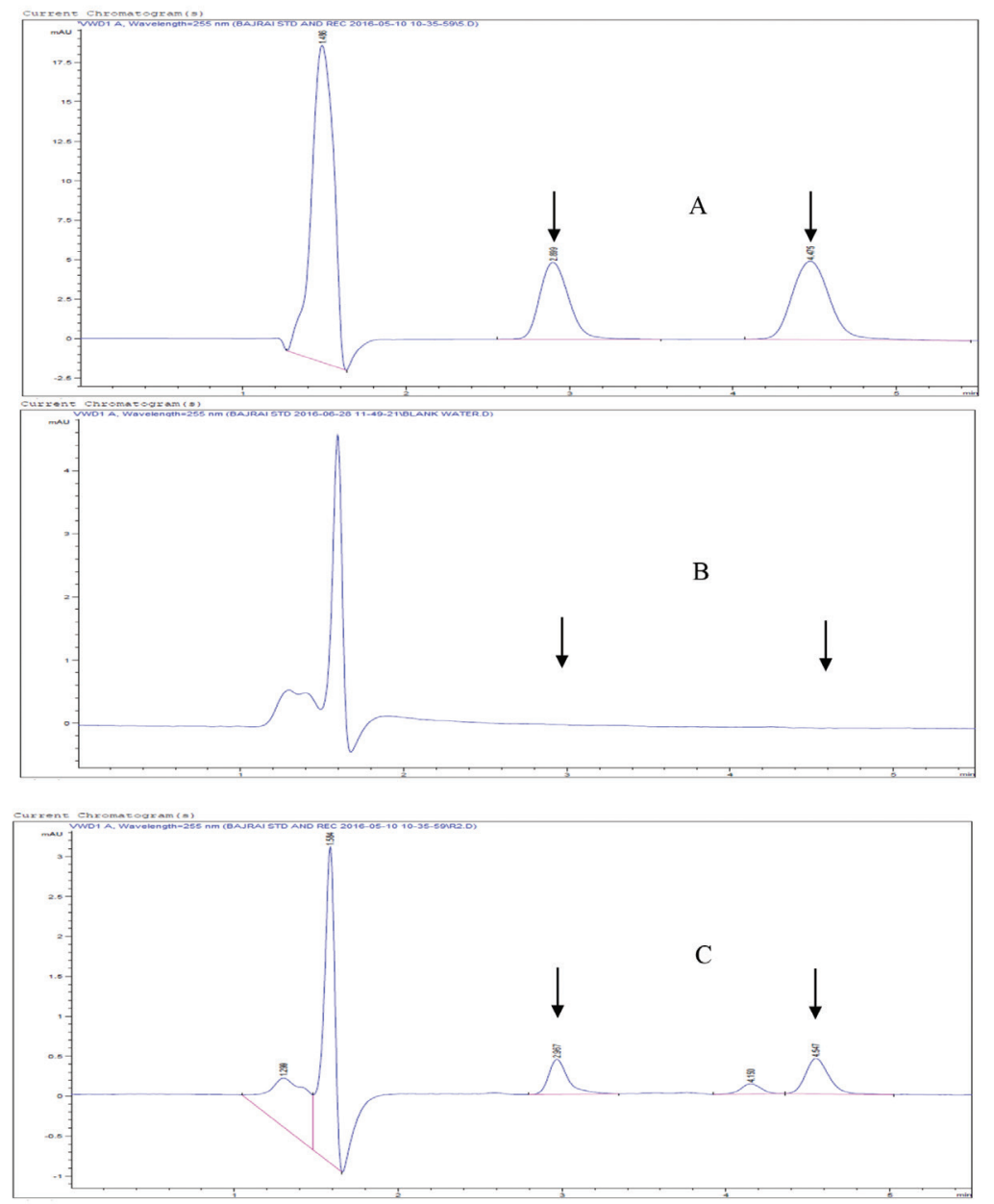

FIGURE 5. Chromatogram Imazapic \& Imazapyr (A) Standard of Imazapic \& Imazapyr at $5 \mu \mathrm{g} / \mathrm{mL}$, (B) Blank, (C) Chromatogram of Imazapic \& Imazapyr in water at the concentration of $5 \mu \mathrm{g} / \mathrm{mL}$ with respect to 15 times dilution

finding of the present study whereby the $\mathrm{m} / \mathrm{z}$ of 276 was obtained for the imazapic compound (Cesio et al. 2011; Pareja et al. 2011).

\section{CONCLUSION}

Analytical methods for determining residues of herbicides have various constraints such as excessive use of organic solvents and complicated steps for analysis. The improvement of existing methods of analysis is essential to determine imazapic and imazapyr residues in various environmental media with one single analysis. It would certainly save time and energy compared to tedious analyses that had to be conducted separately in order to determine both the herbicides in the two mediums namely; soil and water. The optimization method of detection of imazapic and imazapyr started with selecting three parameters in HPLC-UV system which included the selection of the mobile phase, UV wavelength and flow rate of the mobile phase. From the results obtained, the use of acetonitrile and formic acid at a ratio (80:20) at the flow rate of $0.3 \mathrm{~mL} / \mathrm{min}$ and selected UV wavelength at $255 \mathrm{~nm}$ was the most suitable parameters in this system. Optimization of HPLC-UV system was carried out to obtain the best operating conditions as well as achieving the most appropriate chromatogram for imazapic and imazapyr following the residue analyses. Several extraction methods with slight modifications were conducted for both soil and water to detect imazapic and imazapyr residues using various organic solvents and a combination of solvent solution with $\mathrm{C}_{18}$ and SCX SPE cartridges. Further verification and validation of analytical methods was carried out using parameters such as repeatability, precision and percent recoveries.

The percentage of recovery for imazapic and imazapyr using $10 \mu \mathrm{M}$ ammonium acetate in soil and water samples scored in a good range between $83-97 \%$ and $88-106 \%$ and the \% RSD for both mediums is less than $9 \%$, while the LOD of imazapic and imazapyr were achieved at $0.45 \mathrm{mg} \mathrm{L}^{-1}$ and $0.25 \mathrm{mg} \mathrm{L}^{-1}$, respectively. The compound mass spectrum analysed using LC-MS (ToF) in order to validate the specified compounds in soil and water was obtained at $\mathrm{m} / \mathrm{z} 262.12$ with the retention time of $2.39 \mathrm{~min}$ for imazapyr and at $\mathrm{m} / \mathrm{z} 276.13$ with the retention time of $3.06 \mathrm{~min}$ for imazapic. Previous studies extracted the 

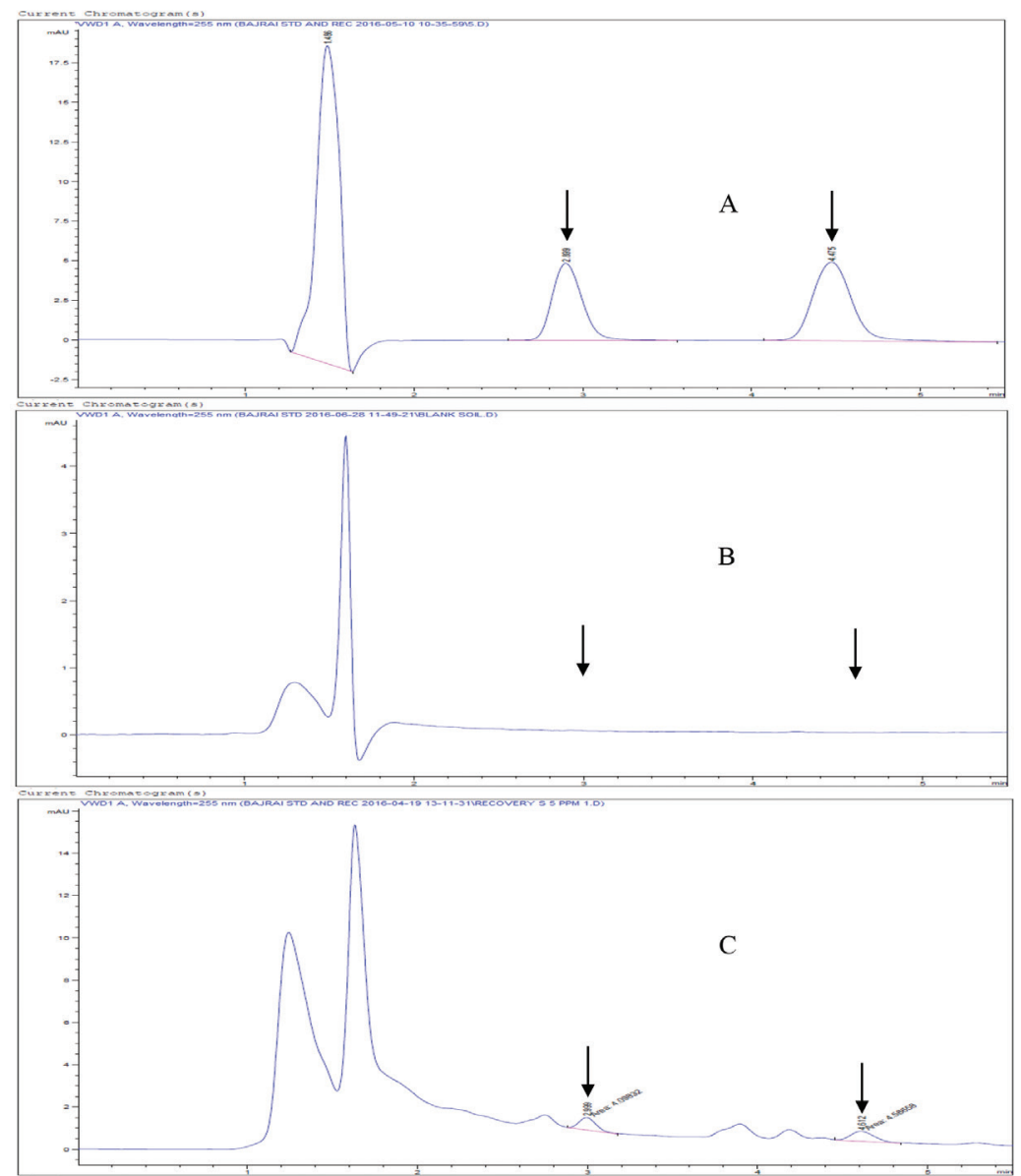

FIGURE 6. Chromatogram Imazapic \& Imazapyr (A) Standard of Imazapic \& Imazapyr at $5 \mu \mathrm{g} / \mathrm{mL}$, (B) Blank, (C) Chromatogram of Imazapic \& Imazapyr in soil at the concentration of $5 \mu \mathrm{g} / \mathrm{mL}$ with respect to 10 times dilution

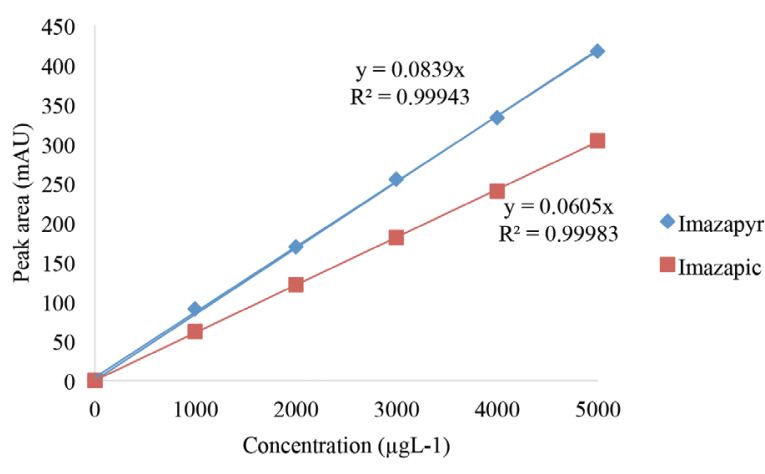

FIGURE 7. Maximum absorption in relation to concentration

imidazolinone herbicides using higher concentrations of organic solvents and required multiple usages of SPE cartridges. Their extraction methods also had to be conducted separately for both types of herbicide or might give higher recovery to only one media while lower recovery for the other media. Individual analysis would increase the costs of extraction, take a longer time and increase the use of chemicals for extraction. The modified and validated method can therefore be used to analyse the

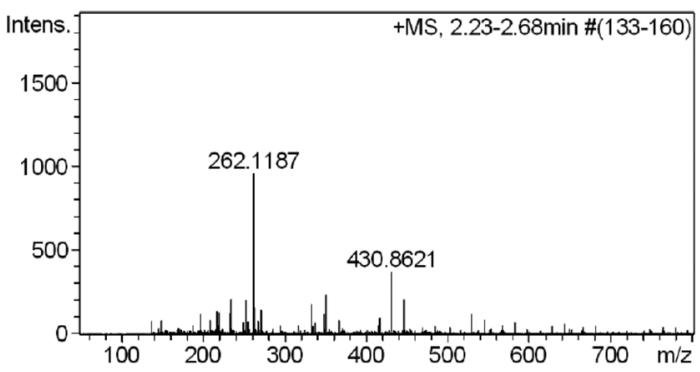

(a)

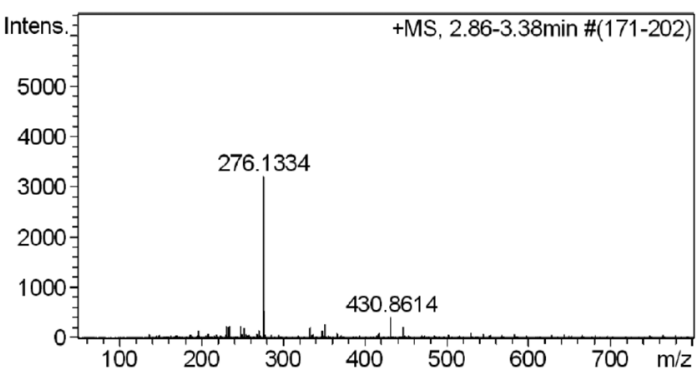

(b)

FIGURE 8. Compound mass spectrum of (a) Imazapyr and (b) Imazapic from analysis of LC-MS (ToF) 
presence of imazapic and imazapyr residues in different soil and water samples by using lower concentrations of solvent solution.

\section{ACKNOWLEDGEMENTS}

The authors are grateful for the GUP-2014-087 grant, from BASF Malaysia (ST2015-011) and to Universiti Kebangsaan Malaysia for the financial support.

\section{REFERENCES}

Akkbik, M., Assim, Z.B. \& Ahmad, F.B. 2011. Optimization and validation of RP-HPLC-UV/Vis method for determination phenolic compounds in several personal care products. International Journal of Analytical Chemistry. 2011: Article ID. 858153. doi:10.1155/2011/858153.

Assalin, M.R., Queiroz, S.C., Ferracini, V.L., Oliveira, T., Vilhena, E. \& Mattos, M.L.T. 2014. A method for determination of imazapic and imazethapyr residues in soil using an ultrasonic assisted extraction and LC-MS/MS. Bulletin of Environmental Contamination and Toxicology 93(3): 360-364.

Azmi, M., Azlan, S., Yim, K., George, T. \& Chew, S. 2012. Control of weedy rice in direct-seeded rice using the Clearfield production system in Malaysia. Pakistan Journal of Weed Science Research 18(Special Issue): 49-53.

Bajrai, F.S.M., Ismail, B.S. \& Mardiana-Jansar, K. 2015. Rapid diagnosis of imazapic \& imazapyr resistance by using bioassays in Clearfield ${ }^{\circledast}$ production system, Malaysia. AIP Conference Proceedings 1678(1): 020008.

Börjesson, E., Torstensson, L. \& Stenström, J. 2004. The fate of imazapyr in a Swedish railway embankment. Pest Management Science 60(6): 544-549.

Cesio, V., Fernandez-alba, A.R., Bocking, B., García, C., Fernandez, G., Heinzen, H., Asteggiante, L.G., Pareja, L. \& Niell, S. 2011. Critical Revision and Development Perspectives of Herbicide Residues Analysis in Agro Ecosystems. INTECH Open Access Publisher.

D’Ascenzo, G., Gentili, A., Marchese, S., Marino, A. \& Perret, D. 1998. Optimization of high performance liquid chromatography/mass spectrometry apparatus for determination of imidazolinone herbicides in soil at levels of a few ppb. Rapid Communications in Mass Spectrometry 12(19): 1359-1365.

de Oliveira Arias, J.L., Rombaldi, C., Caldas, S.S. \& Primel, E.G. 2014. Alternative sorbents for the dispersive solid-phase extraction step in quick, easy, cheap, effective, rugged and safe method for extraction of pesticides from rice paddy soils with determination by liquid chromatography tandem mass spectrometry. Journal of Chromatography A 1360: 66-75.

Devault, D.A., Merlina, G., Lim, P., Probst, J.L. \& Pinelli, E. 2007. Multi-residues analysis of pre-emergence herbicides in fluvial sediments: Application to the Mid-Garonne River. Journal of Environmental Monitoring 9(9): 1009-1017.

Furlong, E.T., Burkhardt, M.R., Gates, P.M., Werner, S.L. \& Battaglin, W.A. 2000. Routine determination of sulfonylurea, imidazolinone, and sulfonamide herbicides at nanogramper-litre concentrations by solid-phase extraction and liquid chromatography/mass spectrometry. Science of the Total Environment 248(2): 135-146.

Gianelli, V.R., Bedmar, F. \& Costa, J.L. 2014. Persistence and sorption of imazapyr in three Argentinean soils. Environmental Toxicology and Chemistry 33(1): 29-34.
Karim, R.S., Man, A.B. \& Ismail, B.S. 2004. Weed problems and their management in rice fields of Malaysia: An overview. Weed Biology and Management 4(4): 177-186.

Kemmerich, M., Bernardi, G., Adaime, M.B., Zanella, R. \& Prestes, O.D. 2015. A simple and efficient method for imidazolinone herbicides determination in soil by ultrahigh performance liquid chromatography-tandem mass spectrometry. Journal of Chromatography A 1412: 82-89.

Krynitsky,A.,Stout, S., Nejad,H.\& Cavalier,T. 1999. Multiresidue determination and confirmation of imidazolinone herbicides in soil by high-performance liquid chromatography/ electrospray ionization mass spectrometry. Journal of AOAC International 82(4): 956-962.

Krüger, M., Schledorn, P., Schrödl, W., Hoppe, H.W., Lutz, W. $\&$ Shehata, A.A. 2014. Detection of glyphosate residues in animals and humans. Journal of Environmental \& Analytical Toxicology 4(2): 1-5.

Laganà, A., Fago, G. \& Marino, A. 1998. Simultaneous determination of imidazolinone herbicides from soil and natural waters using soil column extraction and off-line solid-phase extraction followed by liquid chromatography with UV detection or liquid chromatography/electrospray mass spectroscopy. Analytical Chemistry 70(1): 121-130.

Lao, W.\& Gan, J. 2006. High-performance liquid chromatographic separation of imidazolinone herbicide enantiomers and their methyl derivatives on polysaccharide-coated chiral stationary phases. Journal of Chromatography A 1117(2): 184-193.

Lee, Y.J., Choi, J.H., El-Aty, A.A., Im, S J., Rahman, M.M., Kim, S.W. \& Shim, J.H. 2015. Residue analysis of orthosulfamuron herbicide in fatty rice using liquid chromatography-Tandem mass spectrometry. Journal of Advanced Research 6(3): 511-516.

Lin, K., Xu, C., Zhou, S., Liu, W. \& Gan, J. 2007. Enantiomeric separation of imidazolinone herbicides using chiral high performance liquid chromatography. Chirality 19(3): 171178.

Martini, L.F.D., Mezzomo, R.F., de Avila, L.A., Massey, J.H., Marchesan,E.,Zanella, R., Peixoto, S.C., Refatti, J.P., Cassol, G.V.\& Marques, M. 2013. Imazethapyr and imazapic runoff under continuous and intermittent irrigation of paddy rice. Agricultural Water Management 125: 26-34.

Martins, G.L., Friggi, C.A., Prestes, O.D., Vicari, M.C., Friggi, D.A., Adaime, M.B. \& Zanella, R. 2014. Simultaneous LcMs/Ms determination of imidazolinone herbicides together with other multiclass pesticide residues in soil. CLEAN - Soil, Air, Water 42(10): 1441-1449.

Moser, S.C. 2010. A fast and easy method for Imidazolinone residue analysis. 20th Annual Quality Assurance Conference Presentation, Dallas I, Texas. 19 October 2010.

Pareja, L., Martínez-Bueno, M.J., Cesio, V., Heinzen, H. \& Fernández-Alba, A.R. 2011. Trace analysis of pesticides in paddy field water by direct injection using liquid chromatography-quadrupole-linear ion trap-mass spectrometry. Journal of Chromatography A 1218(30): 4790-4798.

Ramezani, M., Simpson, N., Oliver, D., Kookana, R., Gill, G. \& Preston, C. 2009. Improved extraction and cleanup of imidazolinone herbicides from soil solutions using different solid-phase sorbents. Journal of Chromatography A 1216(26): 5092-5100.

Rekha, Naik, S.N. \& Prasad, R. 2006. Pesticide residue in organic and conventional food-risk analysis. Journal of Chemical Health and Safety 13(6): 12-19. 
Rodriguez, M. \& Orescan, D.B. 1998. Confirmation and quantitation of selected sulfonylurea, imidazolinone, and sulfonamide herbicides in surface water using electrospray LC/MS. Analytical Chemistry 70(13): 2710-2717.

Saadati, N., Md Pauzi Abdullah, Zuriati Zakaria, Seyedeh Belin Tavakoli Sany, Majid Rezayi \& Houshang Hassonizadeh. 2013. Limit of detection and limit of quantification development procedures for organochlorine pesticides analysis in water and sediment matrices. Chemistry Central Journal 7: 63.

Saito-Shida, S., Nemoto, S., Teshima, R. \& Akiyama, H. 2016. Determination of rodenticide tetramethylenedisulfotetramine (tetramine) in processed foods by gas chromatographyTandem mass spectrometry. Shokuhin eiseigaku zasshi. Journal of the Food Hygienic Society of Japan 57(3): 72-75.

Senseman, S.A., Armbrust, K. \& America, W.S.S. 2007. Herbicide Handbook. Lawrence: Weed Science Society of America.

Singh, R. 2013. HPLC method development and validationan overview. Journal of Pharmaceutical Education and Research 4(1): 26-33.

Süzer, S. \& Büyük, H. 2010. Residual effects of spraying imidazolinone-family herbicides on Clearfield® sunflower production from the point of view of crop rotation. Helia 33(52): 25-36

Terano, R., Mohamed, Z. \& Din, N.S.Z. 2016. Determinants of farmers' adoption of clearfield production system in Malaysia. Agriculture and Agricultural Science Procedia 9: 103-107.

Tian, C., Wang, M., Liu, X., Wang, H. \& Zhao, C. 2014. HPLC quantification of nine chemical constituents from the five parts of Abutilon theophrasti medik. Journal of Chromatographic Science 52(3): 258-263.
Tu, M., Hurd, C. \& Randall, J.W. 2001. Control Methods Handbook: Tools and Techniques for Use in Natural Areas. The Nature Conservancy, Wildland Invasive Species Team. http://tncweeds.ucdavis.edu/handbook.html. Accessed on 7 May 2016.

Ulbrich, A.V., Souza, J.R.P. \& Shaner, D. 2005. Persistence and carryover effect of imazapic and imazapyr in Brazilian cropping systems 1. Weed Technology 19(4): 986-991.

Xavier, R., Rekha, K. \& Bairy, K. 2004. Health perspective of pesticide exposure and dietary management. Malaysian Journal of Nutrition 10(1): 39-51.

Wee, C.S., Ariff, M.S.B.M., Zakuan, N., Tajudin, M.N.M., Ismail, K. \& Ishak, N. 2014. Consumers perception, purchase intention and actual purchase behavior of organic food products. Review of Integrative Business and Economics Research 3(2): 378-397.

School of Environmental and Natural Resource Sciences Faculty of Science \& Technology

Universiti Kebangsaan Malaysia 43600 UKM Bangi, Selangor Darul Ehsan Malaysia

*Corresponding author; email: ismail@ukm.edu.my

Received: 5 December 2016

Accepted: 22 March 2017 